GEOLOGICAL SURVEY CIRCULAR 711

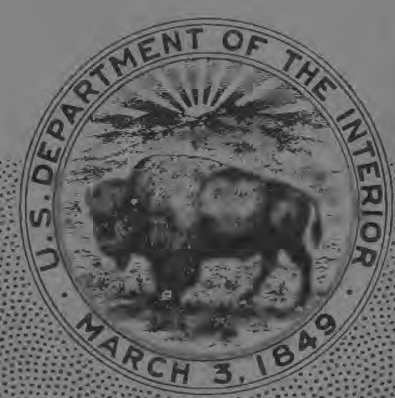

\title{
Preliminary Results of Geochemical Soil Survey, Hamme Tungsten District, North Carolina
}




\section{Preliminary Results of Geochemical Soil Survey,}

Hamme Tungsten District, North Carolina

By Jacob E. Gair, John F. Windolph, Jr., and Nancy A. Wright

GEOLOGICAL SURVEY CIRCULAR 7II

Trace-element values in soil are related to major underlying rock units and to tungsten mineralization and indicate a large bismuth-copper-molybdenum anomaly west of the principal mineral deposit 


\section{United States Department of the Interior ROGERS C. B. MORTON, Secretary}

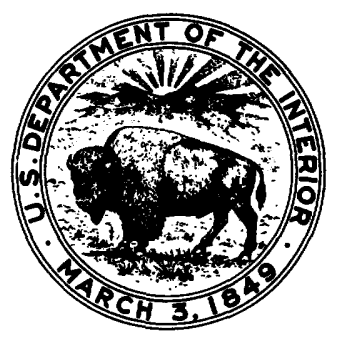

\section{Geological Survey}

V. E. McKelvey, Director

\section{Library of Congress Cataloging in Publication Data}

Gair, Jacob Eugene, 1922-

Preliminary results of geochemical soil survey.

(Geological Survey circular; 711)

Bibliography: p.

Supt. of Docs. no.: I 19.4/2:711

1. Tungsten. 2. Geochemistry. 3. Ore-deposits-North Carolina-Vance Co. 4. Soils-North Carolina-Vance Co. I. Windolph, John F., joint author. II. Wright, Nancy A., joint author. III. Title. IV. Series: United States. Geological Survey. Circular. 711.

QE75.C5 no. 711 [QE516.W1] 557.3'08s [553'.464] 74-28240 


\section{CONTENTS}

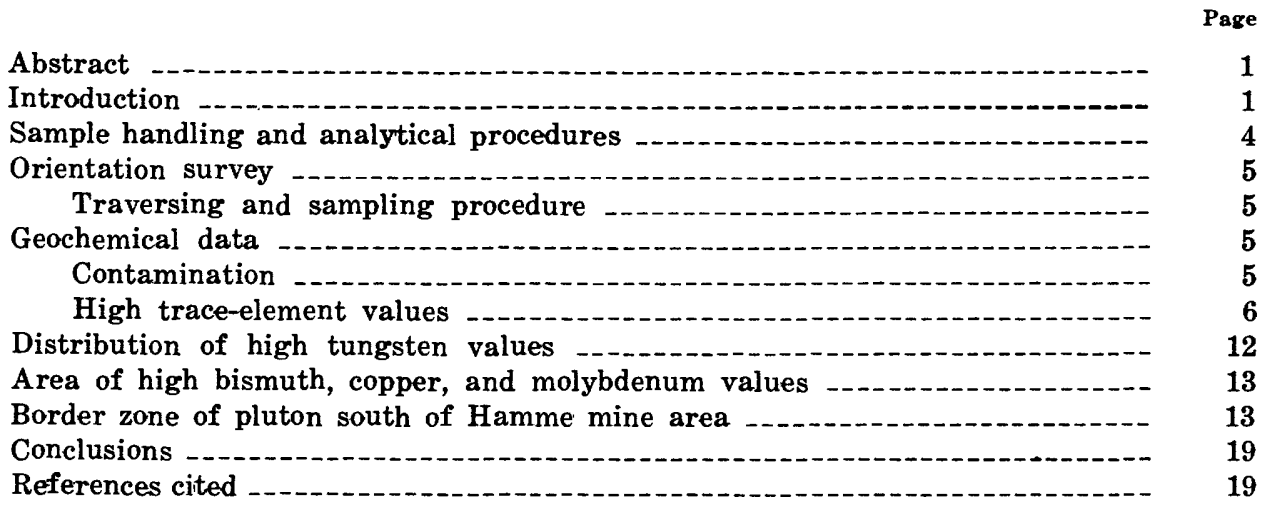

\section{ILLUSTRATIONS}

FIGURE 1. Map showing location of soil-sampling traverses and principal geologic features, Hamme tungsten district, North Carolina.2. Diagrams showing comparison of trace-element values at 0 - to 1 foot $(0-0.3 \mathrm{~m})$ and $1-$ to 2 -foot $(0.3-0.6 \mathrm{~m})$ depths

3. Isopleth maps of geochemical data showing areas of high bismuth, copper, and molybdenum values

\section{TABLES}

TABLE 1. Examples of analytical data from two soil-sample traverses --.--

2. Trace-element statistics-mean values, deviation, and arbitrary geochemical threshold-in soil samples from granitic rock and phyllite areas

3. Clustering indexes in selected traverses of area $A$ 



\title{
Preliminary Results of Geochemical Soil Survey, Hamme Tungsten District, North Carolina
}

\author{
BY JACOB E. GAIR, JOHN F. WINDOLPH, JR., and NANCY A. WRIGHT
}

\begin{abstract}
The results of a geochemical soil survey above the Hamme tungsten deposit, North Carolina, indicate that geochemical exploration techniques are a workable but limited method for searching for tungsten in similar geologic environments elsewhere in the Piedmont. The principal tungsten mineral of the Hamme deposit, huebnerite, occurs in quartz veins associated with fluorite and commonly containing accessory pyrite, sphalerite, galena, and chalcopyrite, and, in places, tetrahedrite. Scheelite is minor. The mineralized veins trend mainly northeast in the marginal part of a granodiorite-tonalite pluton and in nearby metavolcanic phyllite of the Carolina slate belt. Vein quartz float containing huebnerite occurs in soil for as much as several hundred feet downslope from veins. The limit of detection for tungsten, 50 parts per million (spectrographic), constitutes an anomalously high value. Values of 50 parts per million to several hundred parts per million tungsten generally occur in soil samples taken directly over known mineralized veins or downslope from veins in areas containing quartz float. Tungsten is probably transported as particles of comminuted huebnerite. Therefore, geochemical evidence in soil for tungsten mineralization is likely to be found only where lenticular mineralized veins are near enough to the surface to be subject to mechanical weathering and where some quartz float occurs in the soil. High copper and molybdenum values occur in a belt about 2,000 feet $(600 \mathrm{~m})$ west of the principal tungsten deposit and apparently are related to a thick quartz vein. Soil samples also were taken 1 to 3 miles (1.6-4.8 km) south of the Hamme tungsten deposit, across the projection of the Hamme mineralized zone. These samples contain some clusters of high tungsten values.
\end{abstract}

\section{INTRODUCTION}

The Hamme district, North Carolina (fig. 1), is the only area in the eastern United States with a history of tungsten mining. The district has been a major producer since World War II and contains the largest known classic example of wolframite-type quartz vein deposits in the United States. Tungsten was discovered in the Hamme district in 1942; mining began in 1943 (Espenshade, 1947, p. 2-3) and was continued with slight interruption until 1963, when it was stopped because of low prices. Mining was started again in 1970 by Ranchers Exploration and Development Corp., but it was stopped in the fall of 1971, after a sharp drop in the price of tungsten. Total production has been about 1 million short ton units of $\mathrm{WO}_{3}$

Tungsten in the Hamme district occurs mainly in huebnerite, the manganese end member of the wolframite series, and in much lesser amounts in scheelite. The tungsten minerals occur within massive veins of white quartz occupying several subparallel and crossing zones near the west margin of an elongate northnortheast-trending granodiorite-tonalite pluton. Most production has come from veins in a north-northeast-trending sericitized shear zone within the granitic rock. Most of these veins dip steeply southeast $\left(60^{\circ}-80^{\circ}\right)$. The southwestern part of the zone angles across the edge of the pluton into phyllite of the Carolina slate belt (Parker, 1963, p. 12, 62). Veins entirely within the slate belt rock have been a source of some tungsten production. Two thick diabase dikes of Triassic age trend northnorthwest and cut the mineralized veins and wall rocks. Other mineralized veins which diverge from the principal vein system or lie at a large angle to it generally trend west or northwest. Two of these veins have had some tungsten production. Less productive and barren quartz veins are parallel to and to the west of the main system or can be projected on strike 


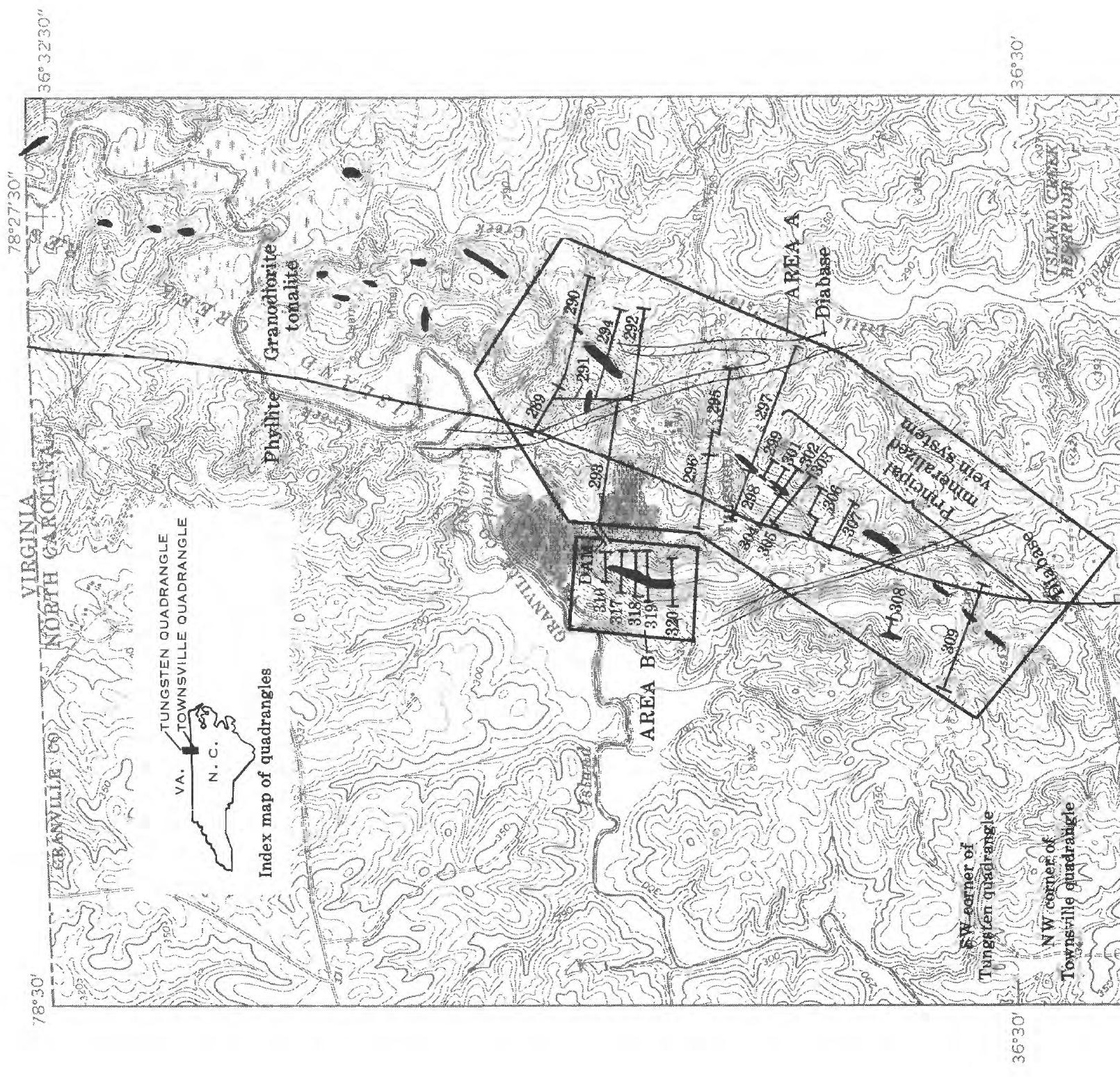




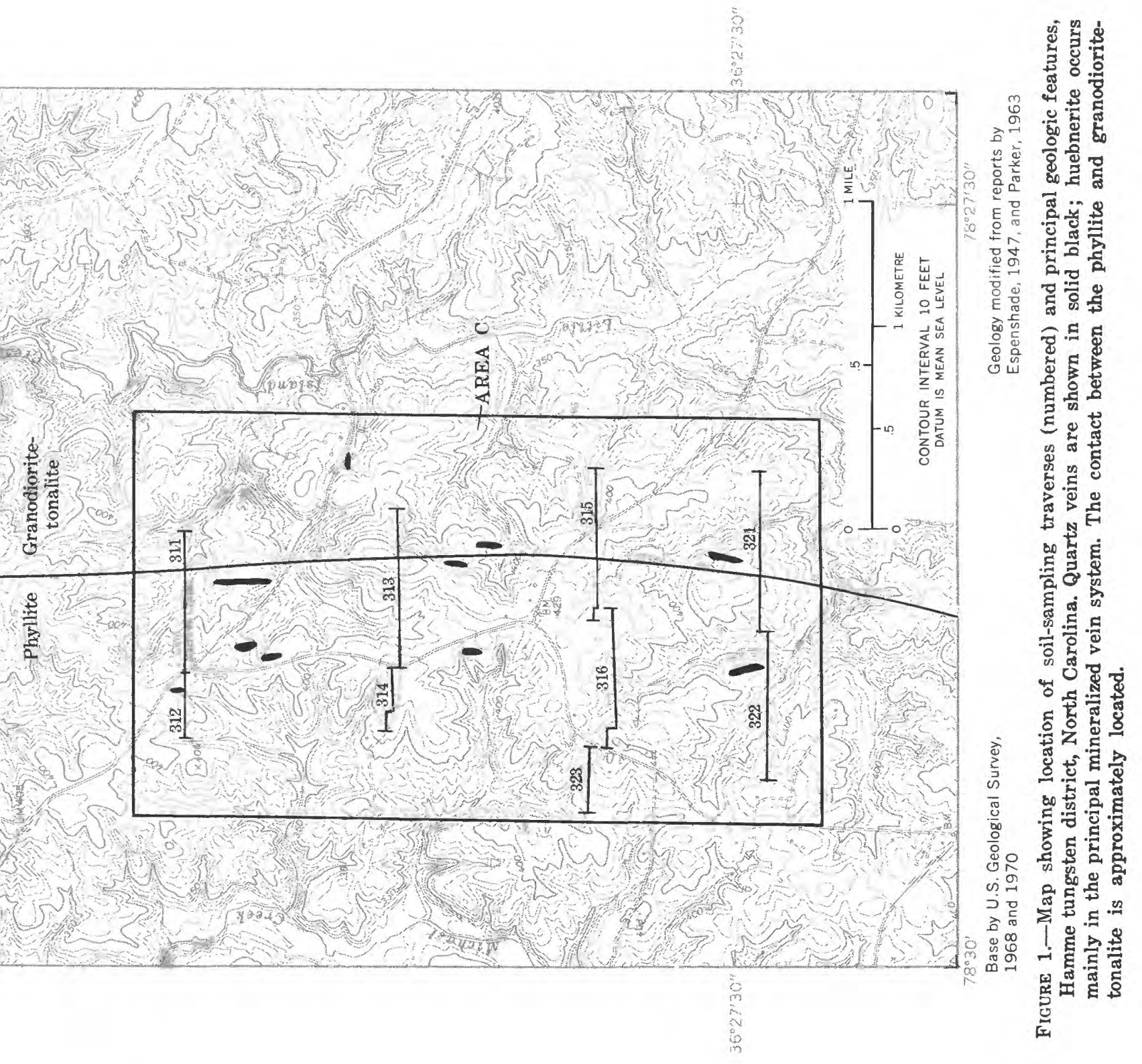


northeast and southwest from the main productive zone. The main productive zone, slightly more than a mile $(1.6 \mathrm{~km})$ long within area $\mathrm{A}$ in figure 1 , and the subsidiary tungsten-bearing veins northeast and southwest of the zone occupy a belt about 8 miles $(13 \mathrm{~km})$ long which extends north of the map area (Espenshade, 1947, p. 2). Veins in the main productive zone consist largely of en echelon quartz pods separated by thin septa of schist. Proceeding from northeast to southwest, the en echelon pods are offset westward. Buckles and drag folds within pods commonly plunge steeply south-southwest to south-southeast; this structure suggests that the gross form of the pods may be that of overlapping steeply plunging ribbons.

Accessory fluorite and sulfide minerals are common in the deposit (Espenshade, 1947, p. 6-9). Pyrite is the most abundant sulfide by far in wall rocks near the veins as well as within the veins. Chalcopyrite, galena, and sphalerite are also common, and tetrahedrite is seen in some places in the veins. Molybdenite and rhodochrosite are comparatively rare. An unidentified mineral, common in films and tiny flakes in the quartz veins, fluoresces bright orange-red and may be pyromorphite of supergene origin (Espenshade, 1947, p. 8).

Chemical weathering has been intense in the area, and soil typically grades into saprolite. In mine workings, effects of weathering have been seen as deep as 50 to 75 feet (15-23 m) below the land surface.

Felsic plutons are known in the Piedmont of the southeastern United States (Butler and Ragland, 1969), but they have not been adequately evaluated as potential sources of mineralization. This study was initiated in 1970 to apply normal techniques of geochemical exploration to determine in the southeast Piedmont environment the influence on trace elements in soils of a classic vein-type (tungsten) deposit associated with a felsic pluton. The results of this study suggest that such techniques could also be applied effectively to preliminary exploration of other felsic plutons in the Piedmont.

An orientation survey (area A in fig. 1) was conducted to establish normal ranges of values for trace elements in soil above known geologic features and distribution patterns of trace elements in soil at various distances from the known mineralized veins. (For discussion of orientation surveys, see Hawkes and Webb, 1962, p. 204.)

This report deals with as many as 12 of the 30 or so trace elements determined in the orientation survey and in additional soil surveys (areas B and C) directly west of, and 1 to 3 miles $(1.6-4.8 \mathrm{~km})$ south of, the main mineralized zone, along the west edge of the granitic pluton. The selected elements are those which, without detailed statistical analysis, appear to vary substantially either along traverses or from one part of the area to another. The selected elements are tungsten, copper, lead, zinc, beryllium, molybdenum, cobalt, nickel, chromium, and fluorine. Additionally, antimony is included for areas $\mathrm{A}$ and $\mathrm{B}$, and bismuth for area B. Antimony was not analyzed for in area $C$; bismuth generally was not present in measurable amounts except in area $B$.

Fieldwork was done by Gair and Windolph, assisted in part by John D'Agostino. Computerized processing of geochemical data was done by Wright.

\section{SAMPLE HANDLING AND ANALYTICAL PROCEDURES}

Samples were ovendried and then broken up; they were ground where necessary to overcome baking together in the drying process. The broken-up and ground material was sieved, and the part that passed 80 mesh was saved for analysis. The samples were not ashed or analyzed for organic content.

All samples were analyzed by a semiquantitative spectrographic method in which values are reported in six geometric classes (Miesch, 1967, p. B3-B4). Molybdenum and, in some traverses, antimony were also tested by colorimetric analysis; copper, lead, and zinc, by atomic absorption; and fluorine, by specific ion test. Although wet-chemical analysis may not necessarily agree closely with a spectrographic analysis for a particular element, corresponding low and high values are generally indicated regardless of the analytical method if the sensitivity of the method permits measurement of the element. 


\section{ORIENTATION SURVEY}

TRAVERSING AND SAMPLING PROCEDURE

The orientation soil survey consisted of sampling traverses to determine geochemical profiles across mineralized quartz veins and associated rocks (fig. 1, area A), especially the north-northeast-trending veins of the principal zone.

Traverses cross veins roughly at right angles and extend from several hundred feet to about 1,500 feet $(100-450 \mathrm{~m})$ beyond any known vein in order to reach beyond the expected influence of the veins and to obtain background data on the trace-element content of soil and saprolite formed from granodiorite-tonalite and phyllite of the Carolina slate belt and Triassic diabase, the principal rock types cut by or cutting the veins. The selected analytical data for the traverses have been arranged in tables that simulate the distribution of sample values along a traverse (table 1; Gair and Windolph, 1975).

The common sampling interval along traverses is 50 feet $(15.2 \mathrm{~m})$. Samples were collected with a 1-inch (about $2.5 \mathrm{~cm}$ )-diameter soil auger. Two or three samples from different depths were taken from each auger hole to test whether different concentrations of trace elements occur at different levels in the soil profile and to compare such differences as might exist. Because of the difficulty of identifying horizons in the soil profile while augeringthe profile never being exposed to view-sampling was done systematically according to distance from the surface rather than by soil horizon. In collecting three samples from an auger hole, an uppermost 6-inch $(15 \mathrm{~cm})$ sample was taken, then a second sample from 6 inches to 1 foot $(15-30 \mathrm{~cm})$ deep, and a third sample from 1 to 2 feet $(30-60 \mathrm{~cm})$ deep. Where only two samples were taken, each is 1 foot $(30 \mathrm{~cm})$ long, one above the other. The samples from the 0- to 1-foot depth include the A soil horizon and generally also the upper part of the $B$ soil horizon. Samples from the 1- to 2-foot depth include mast of the $B$ soil horizon, and most samples also include some saprolite (C soil horizon), a residuum of rock weathered in place, which retains relicts of original texture. The lower samples in each hole inevitably receive some soil dropped from the upper part of the hole, but contamination from this source is considered to be slight, owing to the small amount of added soil. Data in samples from depths of 0 to $1 / 2$ foot and $1 / 2$ to 1 foot (Gair and Windolph, 1975, traverses 299; 301-309) appear to have no systematic variation; in subsequent traverses, the 0 - to 1 -foot zone was generally sampled by 1-foot samples. A comparison of data from 0 - to 1-foot and 1- to 2foot depths (fig. 2) indicates that there is little significant difference for most elements. However, copper, molybdenum ${ }^{1}$, nickel, and fluorine have distinctly higher values at the 1- to 2-foot depth. Values for copper, particularly, may be in the background range in the shallower sample and distinctly higher in the deeper sample at any given site.

The geochemical highs for copper and molybdenum detected in the present study would not have been missed by sampling only to a 1-foot depth, but conceivably elsewhere in the Piedmont, copper and molybdenum values might exist in such a way that clusters of higher than average values occur in the 1 - to 2 -foot zone, but not in the 0 - to 1 -foot zone. Therefore it is advisable that geochemical (soil) explorations for copper and molybdenum in the Piedmont should sample to at least the 2-foot $(60 \mathrm{~cm})$ depth.

\section{GEOCHEMICAL DATA}

The locations of sampling traverses are shown with respect to principal geologic features, mineralized veins, and other major quartz veins on the map (fig. 1).

In general, on casual inspection only, it has not been possible to correlate closely the raw data in a geochemical profile with specific host rock, except for tungsten, which was correlated with mineralized veins in area $A$, and bismuth, copper, and molybdenum, which were correlated with a large quartz vein in area B (fig. 1). Commonly also, underlying diabase is readily recognized by high values of cobalt, nickel, and chromium occurring together in a sample.

\section{CONTAMINATION}

Potentially serious contamination of the soil in terms of trace-element content is likely be-

\footnotetext{
${ }^{1}$ Measurable amounts of molybdenum found only along one of the traverses represented in figure 2 .
} 
TABLE 1.-Examples of analytical data from two soil-sample traverses (area A in figure 1)

For these and corresponding data in other traverses of areas A, B, and C, see Gair and Windolph (1975).

Traverses 290 and 303 . Upper value for each element from $\theta$ to $1 \mathrm{ft}(0-0.3 \mathrm{~m})$ depth; lower value from 1 to $2 \mathrm{ft}(0.3-0.6 \mathrm{~m})$ depth; underlined numbers are at or above geochemical threshold determined for soil derived from granodiorite-tonalite.

Type of analysis: Color., colorimetric; A.A., atomic absorption; S.Q.S., semiquantitative spectrographic; S.I., specific ion.

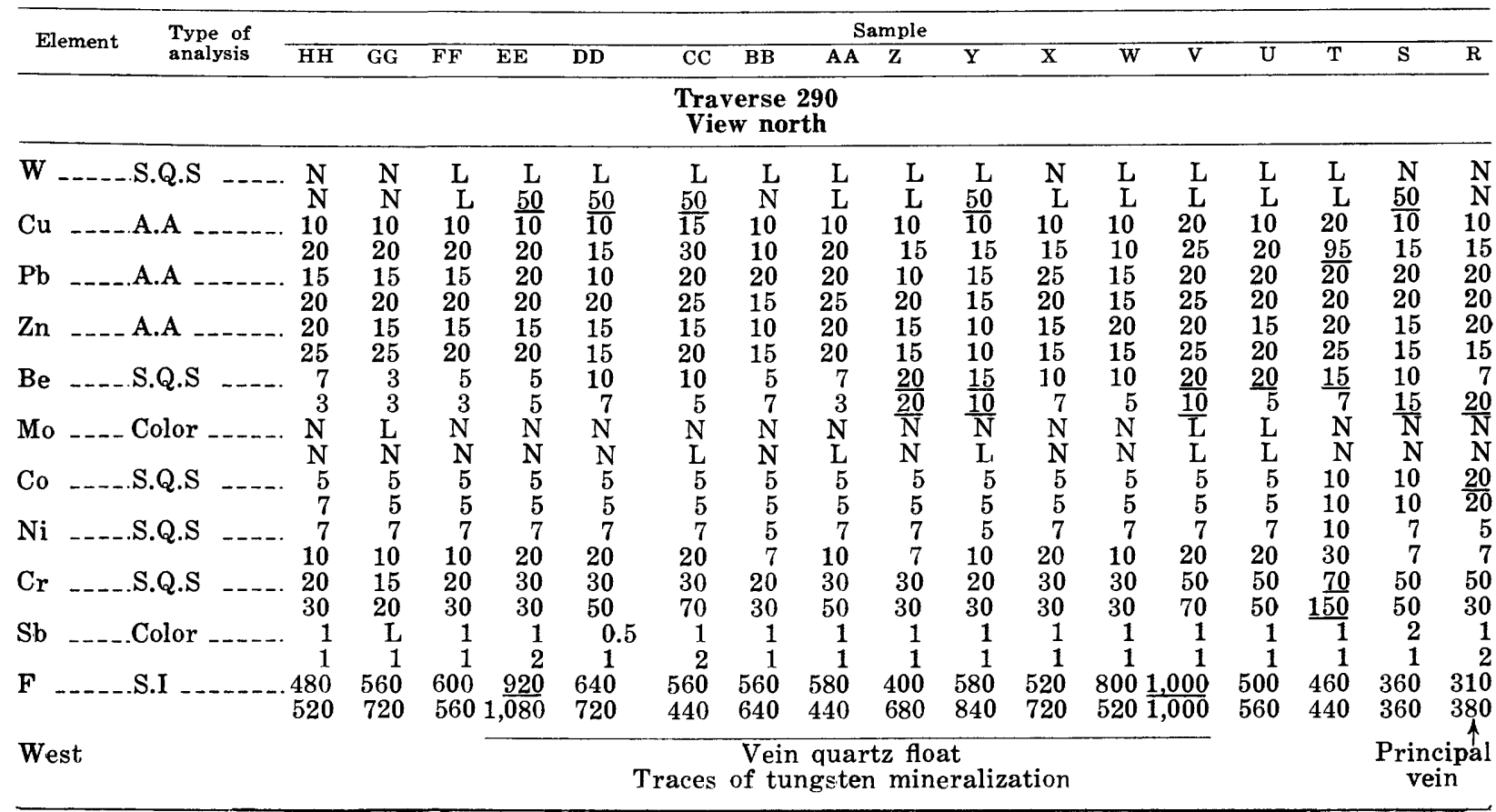

cause of mining and related activity at the Hamme deposit. Care was exercised to avoid some of the obvious pitfalls, but in sampling such an area, probably the best one can hope to do is to minimize the effects of contamination. No samples were taken from disturbed or filled ground other than ordinary fields plowed to depths of about 1 foot $(30 \mathrm{~cm})$. It was assumed initially that ordinary cultivation did not cause significant lateral transport of trace elements, and the data obtained seem to support this assumption. High tungsten values occur at or near the projection of known veins even over plowed ground. Some samples were taken where soil had been removed previously, exposing saprolite. Although such material does not correspond to the normal sample in the weathering profile, it should be free of contamination by foreign material and therefore probably differs from normal samples mainly in being somewhat less weathered. Such material probably corresponds closely to the lowermost 1-foot sample at most of the sample sites. This lowermost sample commonly is partly or entirely saprolite. Probably the best check for the absence of serious contamination in the orientation survey is the occurrence of high metal values where one would expect them, in samples at and adjacent to mineralized veins, and the presence of lower (background) values elsewhere.

\section{HIGH TRACE-ELEMENT VALUES}

As here arbitrarily defined, a high value for a trace element falls in approximately the upper sixth of an array of sample values for the element. Frequency distributions for most elements are approximately lognormal, so the geometric mean is taken as a measure of central tendency (average), and the geochemical threshold for high values is taken as the product of the geometric mean and deviation (table 2), following Bell (1973).

The array of values and the geochemical threshold discussed in this preliminary evaluation are based on the total group of soil samples derived from each major rock type-granitic rock or phyllite-and its included dikes and veins. Average values and geochemical thresholds differ somewhat in soil over different 
TABLE 1.-Examples of analytical data from two soil sample traverses (area A in figure 1) -Continued

Symbols for analytical results: Measurable values given directly in parts per million; L, element detected, but less than limit of measurement; $N$, element not detected at stated limit of measurement.

Limit of measurement (only for Mo and W, having $L$ or $N$ amounts: Mo, 4; W, 50).

Underlying rock is granitic or as noted.

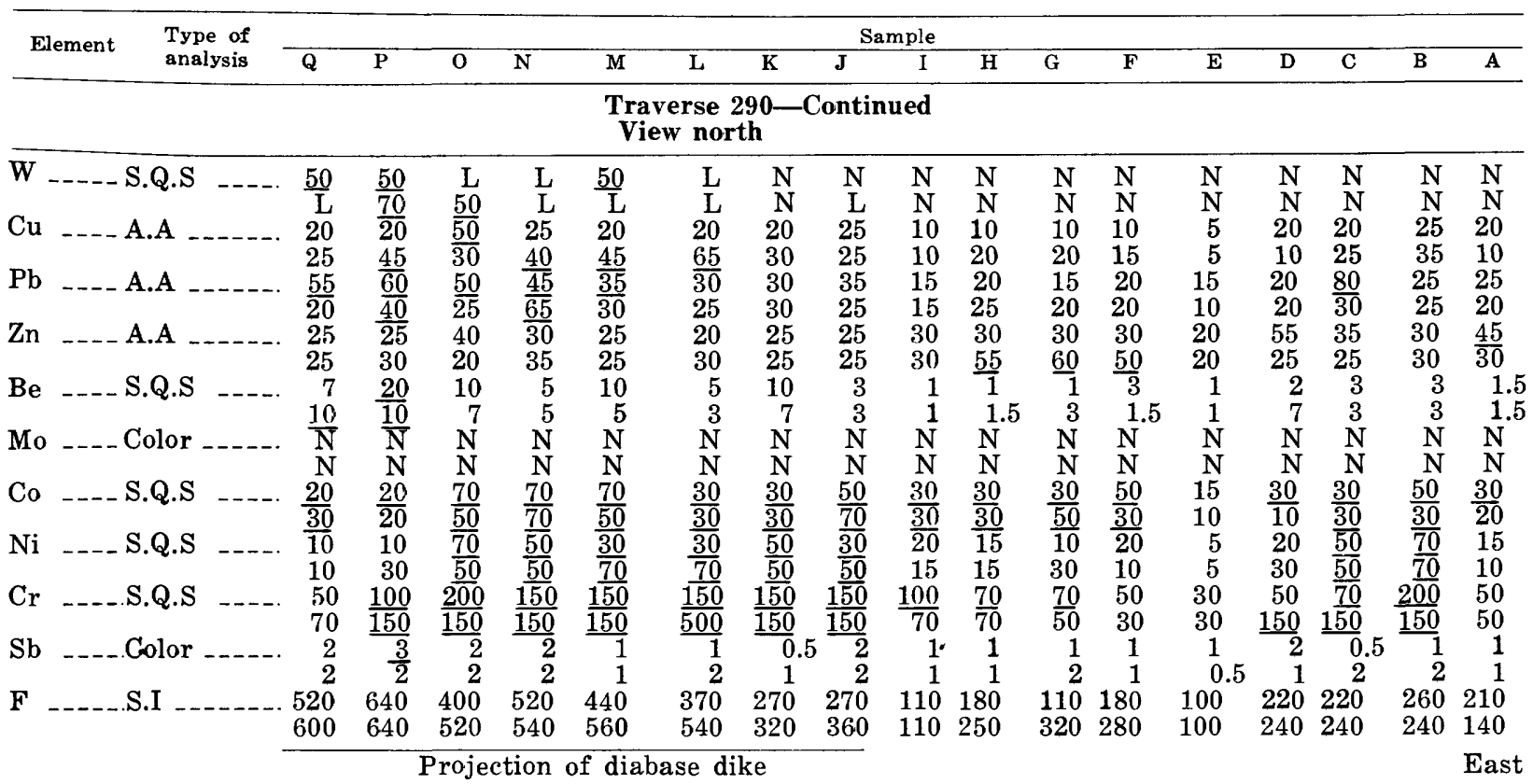

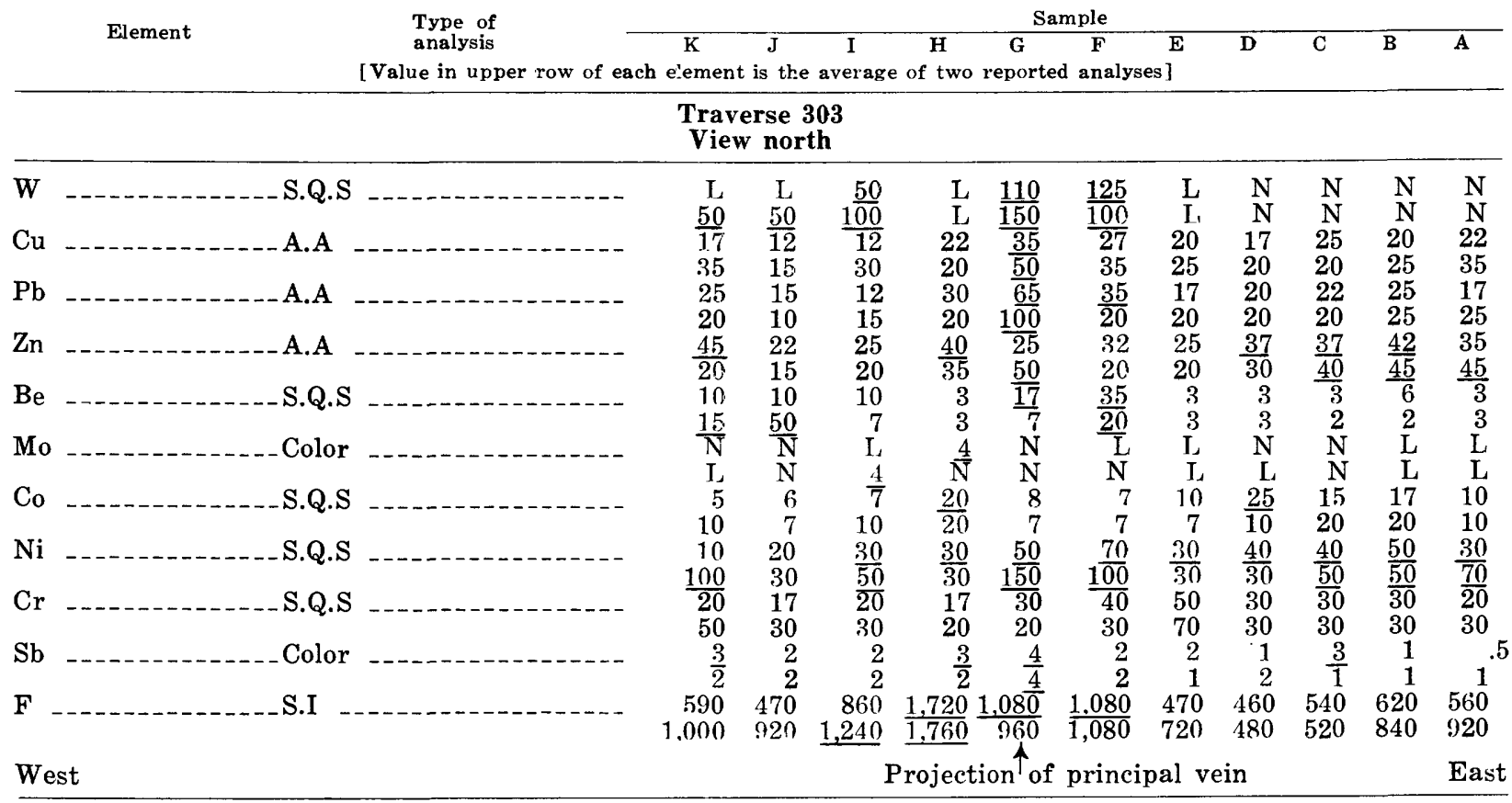

rocks; if the samples considered were restricted to local variants of the granite or phyllite or to their included dikes and veins where average values are markedly above or below the average for the entire unit sampled, threshold values would vary accordingly. Values that are high relative to a selected group of surrounding values and so may be significant for mineral exploration may not be high compared with the total population. Therefore, the threshold values listed herein (table 2), which are based on the total sample population for a major 


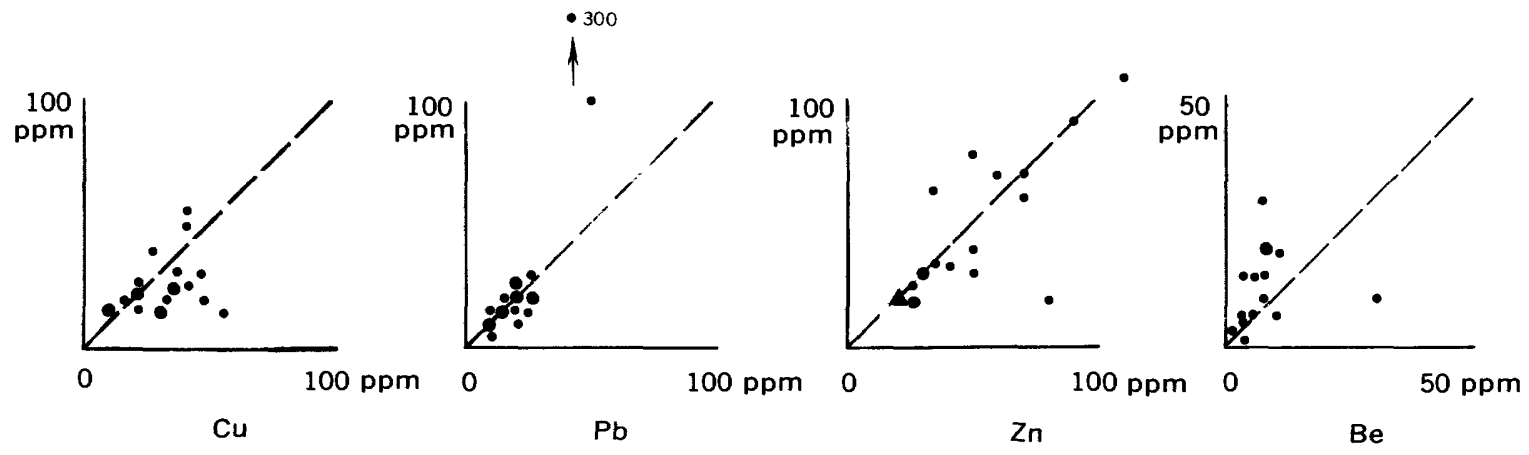

TRAVERSE 289
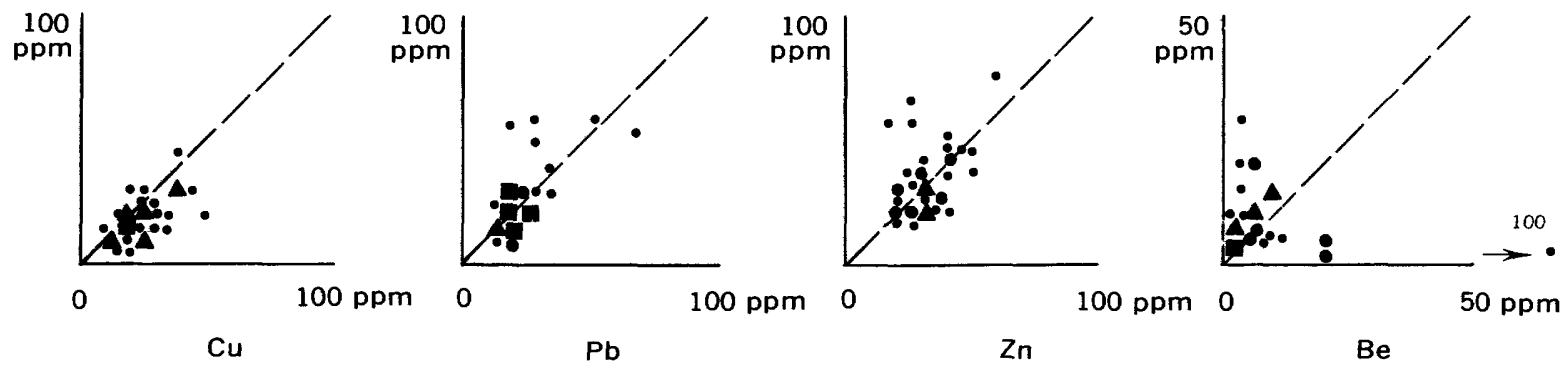

TRAVERSE 297
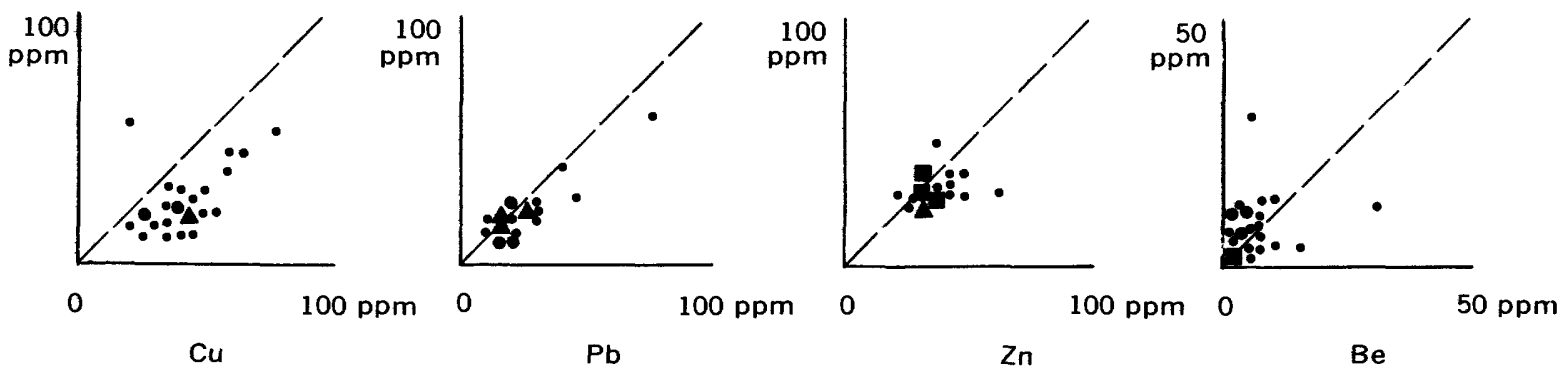

TRAVERSE 309

EXPLANATION

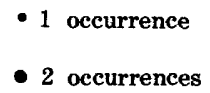

A occurrences

- 2 occurrences

4 or more occurrences

FIgURE 2.-Comparison of trace-element values (parts per million) at 0- to 1-foot (0-0.3 data tabulated in Gair 


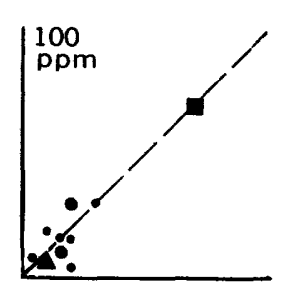

0

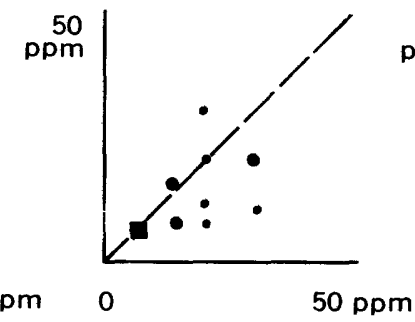

$\mathrm{Ni}$

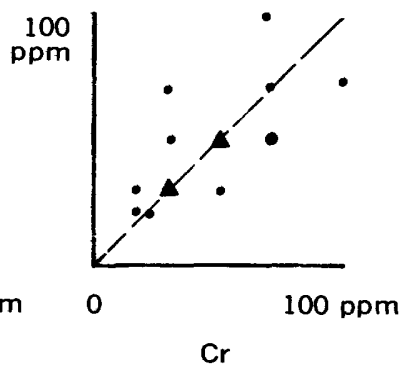

TRAVERSE 289
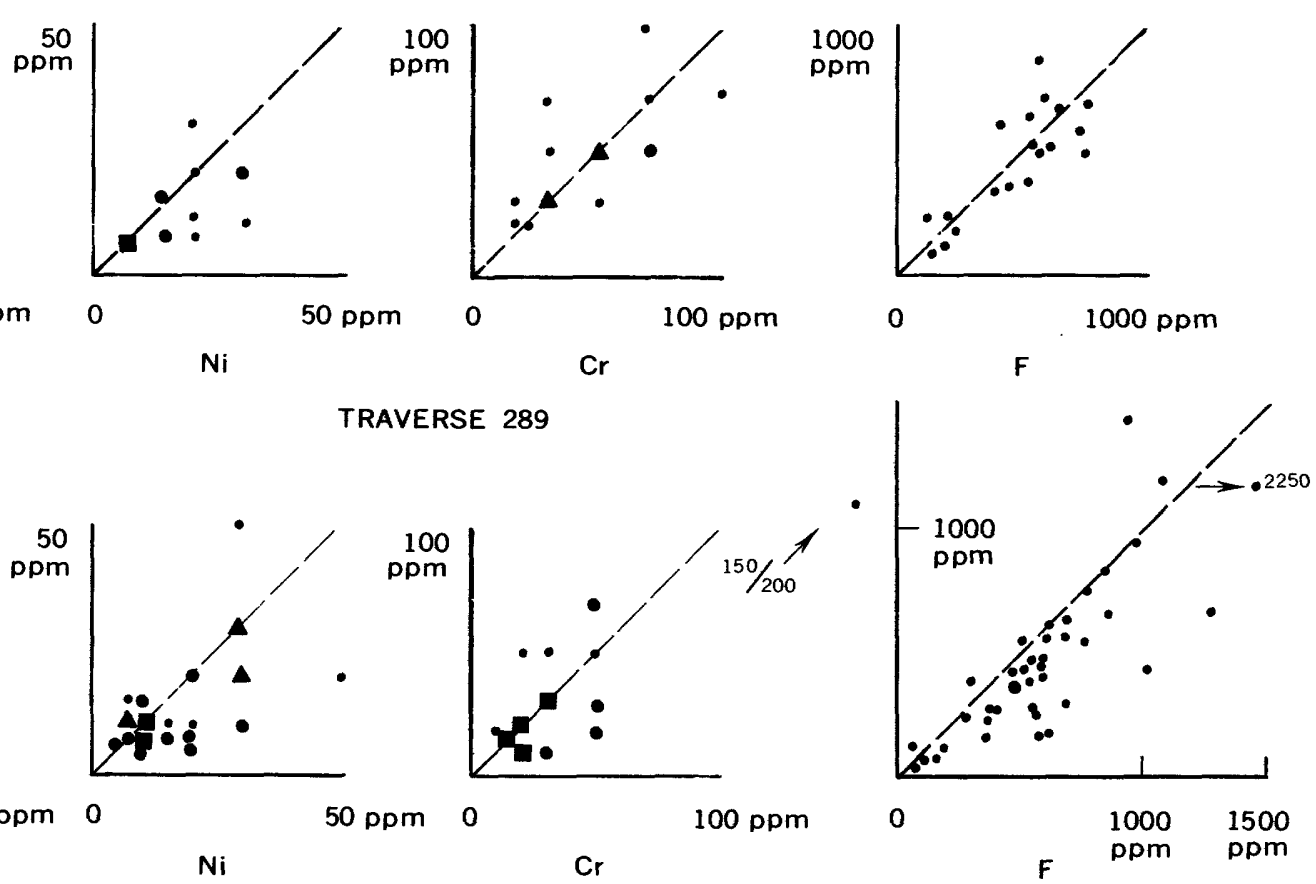

TRAVERSE 297

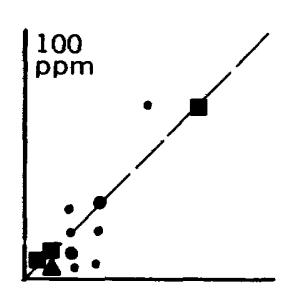

0

100 ppm

Co
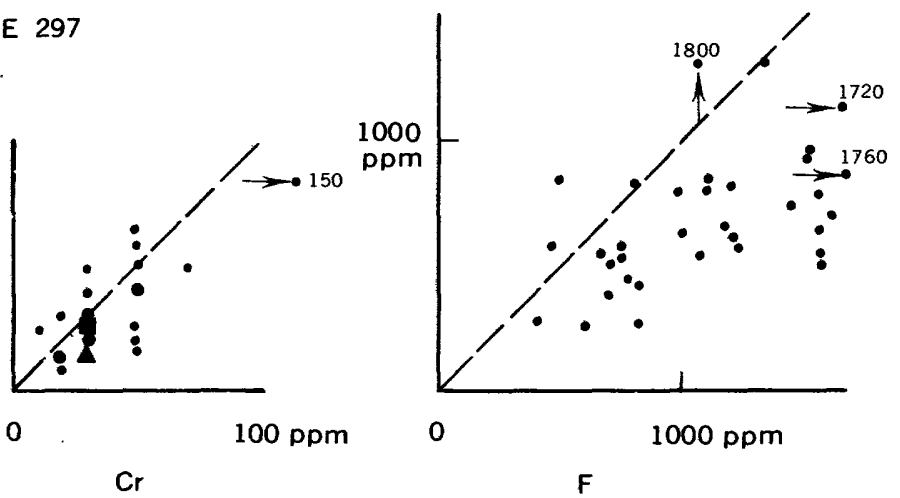

TRAVERSE 309

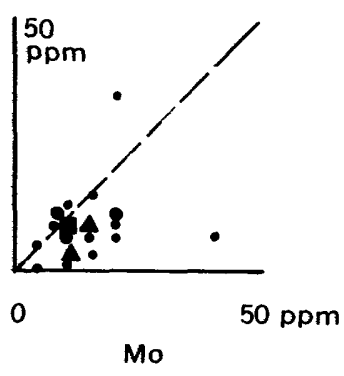

TRAVERSE 309

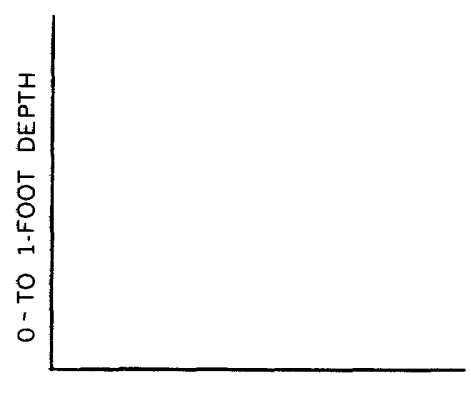

1-TO 2-FOOT DE.PTH

$\mathrm{m})$ and 1 - to 2-foot $(0.3-0.6 \mathrm{~m})$ depths. See figure 1 for traverse locations. Analytical and Windolph (1975). 
TABLE 2.-Trace-element statistics-mean values, deviation, and arbitrary

[Type of analysis shown in parentheses; see

\begin{tabular}{|c|c|c|c|c|c|c|c|c|c|c|}
\hline & \multicolumn{2}{|c|}{ W (S.Q.S.) } & \multicolumn{2}{|c|}{$\mathrm{Cu}$ (A.A.) } & \multicolumn{2}{|c|}{$\mathrm{Pb}$ (A.A.) } & \multicolumn{2}{|c|}{ Zn (A.A.) } & \multicolumn{2}{|c|}{ Be (S.Q.S.) } \\
\hline & $\begin{array}{l}\text { Lower } \\
\mathrm{ft}\end{array}$ & Upper & $\begin{array}{l}\text { Lower } \\
\text { ft }\end{array}$ & $\underset{f t}{\text { Upper }}$ & $\begin{array}{l}\text { Lower } \\
\mathrm{ft}\end{array}$ & $\underset{f t}{U \text { pper }}$ & $\begin{array}{c}\text { Lower } \\
\mathrm{ft}\end{array}$ & $\underset{\mathrm{ft}}{\mathrm{Upper}}$ & $\begin{array}{c}\text { Lower } \\
\mathrm{ft}\end{array}$ & $\begin{array}{c}\text { Upper } \\
\mathrm{ft}\end{array}$ \\
\hline \multicolumn{11}{|c|}{ Granitic rock } \\
\hline Total samples & 405 & 405 & 405 & 405 & 405 & 405 & 405 & 405 & 405 & 405 \\
\hline $\begin{array}{l}\text { Censored values }(N \text { or } L)^{1} \\
\text { Geometric mean }{ }^{3}{ }_{(\text {parts per }}\end{array}$ & 320 & 338 & 0 & 1 & 6 & 4 & 0 & 0 & 16 & 14 \\
\hline $\begin{array}{l}\text { million) } \\
\text { Geometric deviation }{ }^{3} \text { (parts }\end{array}$ & ---- & $\cdots$ & 20.77 & 14.92 & 19.17 & 18.39 & 22.56 & 21.23 & 4.17 & 5.73 \\
\hline $\begin{array}{l}\text { per million) } \\
\text { Geochemical threshold }{ }^{\frac{1}{4}} \text { (parts }\end{array}$ & ---- & -- & 1.84 & 1.85 & 1.78 & 1.91 & 1.70 & 1.75 & 2.51 & 2.50 \\
\hline per million $)^{5}$ & ${ }^{5} 50$ & ${ }^{5} 50$ & 38 & 28 & 34 & 35 & 38 & 37 & 10 & 14 \\
\hline \multicolumn{11}{|c|}{ Phyllite } \\
\hline $\begin{array}{l}\text { Total samples } \\
\text { Censored values }(\mathrm{N} \text { or } \mathrm{L})^{1}\end{array}$ & $\begin{array}{l}381 \\
361\end{array}$ & $\begin{array}{l}383 \\
373\end{array}$ & $\begin{array}{r}381 \\
1\end{array}$ & $\begin{array}{r}383 \\
3\end{array}$ & $\begin{array}{r}381 \\
8\end{array}$ & $\begin{array}{r}383 \\
10\end{array}$ & $\begin{array}{r}381 \\
0\end{array}$ & $\begin{array}{r}383 \\
0\end{array}$ & $\begin{array}{l}381 \\
169\end{array}$ & $\begin{array}{l}383 \\
169\end{array}$ \\
\hline $\begin{array}{l}\text { Geometric mean }{ }^{3} \text { (parts per } \\
\text { million) }\end{array}$ & $-\ldots-$ & & 24.73 & 16.75 & 12.04 & 10.64 & 21.02 & 17.60 & 2.18 & 2.52 \\
\hline $\begin{array}{l}\text { Geometric deviation }{ }^{3} \text { (parts per } \\
\text { million) }\end{array}$ & -- & & 2.36 & 2.29 & 1.57 & 1.65 & 1.84 & 1.77 & 2.05 & 2.24 \\
\hline $\begin{array}{l}\text { Geochemical threshold }{ }^{4} \text { (parts } \\
\text { per million }\end{array}$ & ${ }^{5} 50$ & ${ }^{5} 50$ & 58 & 38 & 19 & 18 & 39 & ${ }^{8} 31$ & ${ }^{9} 5$ & ${ }^{9} 5$ \\
\hline
\end{tabular}

1 Element not detected at stated limit of measurement (N), ot element detected but is below limit of measurement (L).

287 sampies with no values reported in lower foot, and 88 samples with no values reported in upper foot; computations basel on 308 values in lower foot and 303 values in unoer foot.

3 No corrections made for bias that would result from using censored values. Geometric mean and deviation based on reported values only. Reported values equal total samples less censored values. or as otherwise determined for Sb and explained in footnotes 2 and 7 . 4 Geochemical threshold computed as geometric mean $\times$ geometric deviation, rounded to nearest whole number.

rock type, do not preclude lower or higher thresholds in limited areas. Average values of selected elements in segments of the area sampled that represent essentially only the included dikes or veins commonly are above the threshold for the major rock unit as a whole, so the defined threshold, although arbitrary, is useful for identifying such different source rocks within the granite and phyllite.

The geochemical thresholds selected for the various elements are reasonably consistent with the results of the orientation survey; good correlation between the threshold (and higher) values and known dikes and veins provides empirical justification for the chosen levels. Significantly higher threshold levels would provide fewer "high" values and would result accordingly in a poor correlation of "high" values with known dikes and mineral veins; lower threshold levels than those chosen, on the other hand, would result in too wide a distribution of "high" values to permit their correlation with the limited zones containing dikes or mineralized veins. At the chosen level (approximately the upper one-sixth of values for an element), there is a high degree of correlation of certain elements above known mineralized veins and of other elements above diabase. Thus, in soil over mineralized veins, or in dispersion zones commonly within 150 feet of veins, tungsten, copper, lead, beryllium, antimony, and fluorine commonly are at or above threshold values, and over diabase, copper, zinc, cobalt, nickel, and chromium commonly are at or above threshold values. Clusters of high values of these elements also occur at sample sites where veins or diabase are not known. Such clusters may have a variety of causes, the most likely being the presence of veins or dikes that have not been recognized, concentrations of vein or dike float in the soil, and scavenging or concentration of the trace elements by oxides of iron or manganese. Making distinctions between such spurious trace-element concentrations and the significant concentrations is one of the most vexing problems of geochemical exploration, but it may be aided by careful field observations, by noting corresponding changes in the traceelement and iron-manganese content of samples, by measurements of clustering as described below, and by various statistical manipulations of data.

Average values and threshold values vary both with underlying rock type and with depth 
geochemical threshold-in soil samples from granitic rock and phyllite areas

tables 1 and 3 for explanation of abbreviations]

\begin{tabular}{|c|c|c|c|c|c|c|c|c|c|c|c|c|c|}
\hline \multicolumn{2}{|c|}{ Mo (Color.) } & \multicolumn{2}{|c|}{ Co (S.Q.S.) } & \multicolumn{2}{|c|}{ Ni (S.Q.S.) } & \multicolumn{2}{|c|}{ Cr (S.Q.S.) } & \multicolumn{2}{|c|}{$\mathrm{Sb}$ (Color.) } & \multicolumn{2}{|c|}{ Bi (S.Q.S.) } & \multicolumn{2}{|c|}{ F (S.I.) } \\
\hline $\begin{array}{c}\text { Lower } \\
\mathrm{ft}\end{array}$ & $\begin{array}{c}\text { Upper } \\
f t\end{array}$ & $\begin{array}{c}\text { Lower } \\
\mathrm{ft}\end{array}$ & $\underset{f t}{\text { Upper }}$ & $\begin{array}{c}\text { Lower } \\
\mathrm{ft}\end{array}$ & $\underset{\mathrm{ft}}{\text { Upper }}$ & $\begin{array}{c}\text { Lower } \\
\text { ft }\end{array}$ & $\begin{array}{c}\text { Upper } \\
\mathbf{f t}\end{array}$ & $\begin{array}{c}\begin{array}{c}\text { Lower } \\
\text { ft }\end{array} \\
\end{array}$ & $\begin{array}{c}U_{\mathrm{ft}} \text { pper } \\
\end{array}$ & $\begin{array}{c}\text { Lower } \\
\text { ft }\end{array}$ & $\begin{array}{c}\text { Upper } \\
f t\end{array}$ & $\begin{array}{c}\text { Lower } \\
\text { ft }\end{array}$ & $\begin{array}{c}\text { Upper } \\
\mathrm{ft}\end{array}$ \\
\hline \multicolumn{14}{|c|}{ Granitic rock-Continued } \\
\hline $\begin{array}{l}405 \\
364\end{array}$ & $\begin{array}{l}405 \\
391\end{array}$ & $\begin{array}{r}405 \\
1\end{array}$ & $\begin{array}{r}405 \\
0\end{array}$ & $\begin{array}{r}405 \\
1\end{array}$ & $\begin{array}{r}405 \\
1\end{array}$ & $\begin{array}{r}405 \\
0\end{array}$ & $\begin{array}{r}405 \\
0\end{array}$ & $\begin{array}{l}405 \\
210\end{array}$ & $\begin{array}{l}405 \\
214\end{array}$ & $\begin{array}{l}405 \\
403\end{array}$ & $\begin{array}{l}405 \\
405\end{array}$ & $\begin{array}{r}405 \\
20\end{array}$ & $\begin{array}{r}405 \\
43\end{array}$ \\
\hline$-\cdots$ & --- & 11.59 & 10.31 & 17.63 & 11.90 & 43.36 & 35.34 & 1.37 & 1.41 & ---- & ---- & 402 & 362 \\
\hline---- & ---- & 1.89 & 1.93 & 2.15 & 2.01 & 2.05 & 2.01 & 2.32 & 2.04 & ---- & --.-- & 2.71 & 2.45 \\
\hline${ }^{5} 4$ & ${ }^{5} 4$ & 22 & 20 & 38 & 24 & 87 & ${ }^{6} 71$ & 3 & 3 & ${ }^{5} 10$ & 510 & 1,090 & 890 \\
\hline \multicolumn{14}{|c|}{ Phyllite-Continued } \\
\hline $\begin{array}{l}381 \\
290\end{array}$ & $\begin{array}{l}383 \\
297\end{array}$ & $\begin{array}{r}381 \\
0\end{array}$ & $\begin{array}{r}383 \\
3\end{array}$ & $\begin{array}{r}381 \\
0\end{array}$ & $\begin{array}{r}383 \\
1\end{array}$ & $\begin{array}{r}381 \\
1\end{array}$ & $\begin{array}{r}383 \\
1\end{array}$ & $\begin{array}{r}381 \\
7 \\
7\end{array}$ & $\begin{array}{c}383 \\
\div 10\end{array}$ & $\begin{array}{l}381 \\
336\end{array}$ & $\begin{array}{l}383 \\
357\end{array}$ & $\begin{array}{r}381 \\
80\end{array}$ & $\begin{array}{l}383 \\
109\end{array}$ \\
\hline---- & --- & 10.67 & 9.64 & 15.05 & 9.61 & 47.92 & 39.83 & 1.10 & 1.06 & -.--- & $\ldots-$ & 207 & 195 \\
\hline$\ldots-$ & ---- & 1.87 & 1.87 & 1.86 & 2.57 & 1.99 & 1.92 & 1.84 & 1.92 & ---- & $\ldots$. & 3.10 & 2.94 \\
\hline${ }^{5} 4$ & ${ }^{5} 4$ & 20 & 18 & 28 & 25 & 95 & 77 & 2 & 2 & ${ }^{5} 10$ & $=10$ & 640 & 570 \\
\hline
\end{tabular}

${ }^{5}$ Lower limit of sensitivity used instead of computed geochemical threshold vecause of high number of censored values.

$60 \mathrm{ppm}$ used as threshold.

7241 samples not analyzed for Sb in lower foot, and 242 samples not analyzed in unper foot; analyzed population is 139 samples (reported

values) in lower foot and 131 samples in upper foot.

30 ppm used as threshold.

9 Threshold value arbitrarily selected to separate approximately lowe: five-sixths of values from upper one-sixth of values. Values below threshold include 169 censored values.

in the soil profile. For example, in soil from granitic rock, the threshold for copper is 28 ppm at a depth of $0-1$ foot and $38 \mathrm{ppm}$ at a depth of 1-2 feet; in soil from phyllite, the threshold for copper is $38 \mathrm{ppm}$ at $0-1$ foot and $58 \mathrm{ppm}$ at 1-2 feet (table 2). The higher threshold values in soil from phyllite are believed to correspond to a higher average background copper content in the phyllite than in the granitic rock, although data on rock compositions have not been obtained for verification.

The thresholds for high values of molybdenum and tungsten are not readily established even by arbitrary manipulation of analytical data because a large proportion of samples has censored values-below the limits of sensitivity of the analytical method (4 ppm for molybdenum and $50 \mathrm{ppm}$ for tungsten). The sporadically distributed measurable tungsten occurs principally if not solely in areas containing mineralized quartz veins and vein quartz float. The background content of tungsten in the granitic and phyllitic country rock is clearly too low to concentrate measurable amounts in the soil. Similarly, the sporadically distributed measurable molybdenum probably represents mineralized (molybdenum-bearing) rock, whereas the background content of molybdenum in the country rocks is too low to produce measurable amounts in overlying soil. Because the lowest measurable value of molybdenum or tungsten represents mineralized rock, and in effect occurs somewhere within the outer edge of the corresponding geochemical high, the real threshold value is probably less than the lower limit of measurement. However, for practical purposes, $4 \mathrm{ppm}$ molybdenum and $50 \mathrm{ppm}$ tungsten are taken as threshold values.

The values in table 2 for beryllium, cobalt, chromium, copper, nickel, lead, antimony, zinc, and fluorine are derived from a large proportion if not all of the samples (in contrast to values for molybdenum and tungsten), so are used to compute thresholds. For each trace element considered, there is a range of threshold values; values differ for samples taken over granitic rock and phyllite, and for samples from the 0- to 1-foot and 1- to 2-foot depths. Such threshold values are (except for copper, already given) : for beryllium, 10-14 ppm (over granitic rock); for cobalt, 18-22 ppm; for 
chromium, 71-95 ppm; for nickel, 24-38 ppm; for lead, 18-35 ppm; for antimony, 2-3 ppm; for zinc, 31-39 ppm; and for fluorine, 570-1,090 ppm. Nearly half the beryllium analyses in soil from phyllite result in censored values. So, to utilize the large number of both numerical and censored values in computing a threshold for such beryllium, the 169 censored values are considered part of the total array, and a division is made between the lower five-sixths and the upper one-sixth of all values. If this procedure is used for populations that have no censored values, the results are similar to the product of the geometric mean and deviation.

Isolated high values may be part of a background population, so only high values that are spatially clustered or alined are considered significant. The determination of significant degrees and patterns of clustering of high traceelement values is generally hampered by gaps in the spatial distribution of data and requires careful judgement. Widely spaced reconnaissance traverses (such as those in area $\mathrm{C}$ in fig. 1) generally will require followup sampling to determine the lateral extent of any data clusters that may be detected only in profile along a single traverse.

The sample traverses provide a simple means of measuring data clustering in a profile (table 3 for selected traverses in area A). Clustering of high values of the eight vein-affiliated elements (tungsten, copper, lead, zinc, beryllium, molybdenum, antimony, and fluorine) and of the five diabase-affiliated elements (copper, zinc, cobalt, nickel, and chromium) commonly is greatest immediately above or adjacent to known mineralized veins or diabase dikes, although in places greater clustering is caused by float than by source veins or dikes. The index of clustering in table 3 is a measure of the number of high values of these elements at a sample site (adding together high values for the 0 - to 1-foot and 1- to 2-foot depths) plus the number of contiguous high values. The clustering indexes for the vein-affiliated and diabaseaffiliated groups are equated according to the number of elements in each group. An index of 1 for the vein-affiliated elements, for example, might be caused by high values for all eight elements in each of the two samples taken at a single sample site, or for only one of the ele- ments, present in each of the two samples taken at eight contiguous sample sites. Generally an index as high as 1 represents some combination of high values at a sample site plus contiguous high values.

Because of varying dispersion and dilution of the affiliated elements, there is no absolute index of clustering that identifies diabase or mineralized vein quartz. Nevertheless, known mineralized vein material is generally marked by clustering indexes in the range, 0.5 to 2.0 , and diabase, by indexes of 0.6 to 5.0. Clustering indexes of vein-affiliated elements higher than 1 are a strong indicator of mineralization. On the other hand, high clustering indexes for diabase-affiliated elements are found over some zones in the phyllite where no diabase is known. These concentrations probably represent unmapped diabase, or a basaltic precursor in those parts of the phyllite.

The spatial distribution of high values and high indexes of clustering and the dimensions of areas containing clusters of high values will determine how much significance is to be attached to the trace-element data for mineral exploration. The high bismuth, copper, and molybdenum values described below in area $B$ and the wide zone of high tungsten values described below in area $\mathrm{C}$ are the only sizable groups of high values found that are not related to heretofore-known mineralized veins. The high bismuth, copper, and molybdenum values apparently correspond to an area of massive white vein quartz outcrop, which contains little visible evidence of mineralization.

\section{DISTRIBUTION OF HIGH TUNGSTEN VALUES}

Generally the measurable tungsten values are found directly above and within 100 to 200 feet downslope from known mineralized veins. However, tungsten values also occur in isolated clusters at distances of several hundred feet downslope from known veins. Measurable tungsten values also correspond to some areas of huebnerite-bearing vein quartz float not directly related to known veins (for example, see Gair and Windolph, 1975, traverse 294, samples D, E, F, G, H, I ; traverse 306, samples L, $\mathrm{N}, \mathrm{O})$. The highest tungsten values in a cluster are as commonly found downslope from a vein 
as directly above it. The probable explanation for such irregular distribution is that huebnerite is resistant to chemical weathering and contributes to tungsten anomalies mainly as particles of the mineral, which however well comminuted by mechanical weathering, is irregularly distributed in the soil adjacent to veins.

\section{AREA OF HIGH BISMUTH, COPPER, AND MOLYBDENUM VALUES}

A major assemblage of high bismuth, copper, and molybdenum values occurs in soil on a prominent north-trending ridge (fig. 1, area B) 8,000 to 9,000 feet $(2.5-2.8 \mathrm{~km})$ northeast of the southwest corner of the Tungsten $71 / 2$ minute quadrangle and about 2,000 feet $(600$ $\mathrm{m}$ ) west of the principal mineralized veins. The ridge bounds the west side of the new tailings pond constructed by Ranchers Exploration and Development Corp. in conjunction with the reopening of the tungsten mine in 1970. The ridge is underlain by north-trending massive white vein quartz which cuts phyllite of the Carolina slate belt. Most of the quartz is barren in appearance, but some contains weathered-out pits and remnants of limonitic pseudomorphs evidently representing a metallic mineral or minerals. A few randomly collected hand samples of the vein quartz contain values of a few hundred to $1,000 \mathrm{ppm}$ bismuth, copper, and molybdenum.

Five east-west sampling traverses (figs. 1, 3; Gair and Windolph, 1975, traverses 310, 317$320)$ have been made across the ridge without entirely bracketing and delimiting the area of high bismuth, copper, and molybdenum values which is at least 1,200 feet $(365 \mathrm{~m})$ long and 400-800 feet (120-240 m) wide and which evidently extends north, south, and perhaps west beyond the sampled area. Isopleth maps of copper and molybdenum values (copper, $>20$ ppm and molybdenum, $>15$ ppm; fig. 3A, B) show the crest of the anomalies for these elements angling slightly across the crest of the ridge. High bismuth values of $10-200 \mathrm{ppm}$ are more scattered (fig. 3C) than the copper and molybdenum values but commonly occur in clusters of three to five contiguous samples; in traverse 317 , they are present in 12 contiguous samples taken across a zone 550 feet $(168 \mathrm{~m})$ wide. In contrast, bismuth was not detected in most of the samples taken in areas $A$ and $C$, except in traverses 308 and 309, as noted below. The contiguous high values for copper and molybdenum at all or nearly all sample sites are largely responsible for the fairly high clustering indexes at every site. For example, indexes in traverse 319 range from 2 to 3.25 . About three-fourths of a mile $(1.2 \mathrm{~km})$ to the south on an extension of the ridge, traverses 308 and 309 (fig. 1; Gair and Windolph, 1975) also reveal contiguous molybdenum values above background values, and background copper values (especially at the 1- to 2-foot depth) rather persistently above mean values. Also, traverses 308 and 309 are the only others in the survey, besides those in area $B$, that contain measurable values of bismuth in contiguous samples. Clustering indexes in all of traverse 309 are high -2.1 to 6.7 - the greatest clustering being where the principal Hamme vein intersects the ridge. The entire ridge between traverses 309 and 310 may be a bismuth-coppermolybdenum-zone.

\section{BORDER ZONE OF PLUTON SOUTH OF HAMME MINE AREA}

Geochemical soil samples have been collected across the border zone of the granodioritetonalite pluton in area $\mathrm{C}$, along the projection of the principal vein system of the Hamme mine, for 1 to 3 miles $(1.6-4.8 \mathrm{~km})$ south of the south end of area A (see fig. 1). Quartz veins, abundant vein quartz float, and tungsten mineralization are found in places in this area (Espenshade, 1947, pl. 1). As the south end of the principal vein system in the mine is within the phyllite, and known quartz veins to the south occur in a wider zone in the phyllite than in the granodiorite, the traverses have been extended farther across the phyllite than the granodiorite.

Clusters of high tungsten values occur near the west end of traverse 311 and the middle and east end of traverse 313 (Gair and Windolph, 1975). The zone of high values at the east end of traverse 313 is about 300 feet $(95 \mathrm{~m})$ across - which compared with zones of contiguous high tungsten values in the vicinity of the mine 


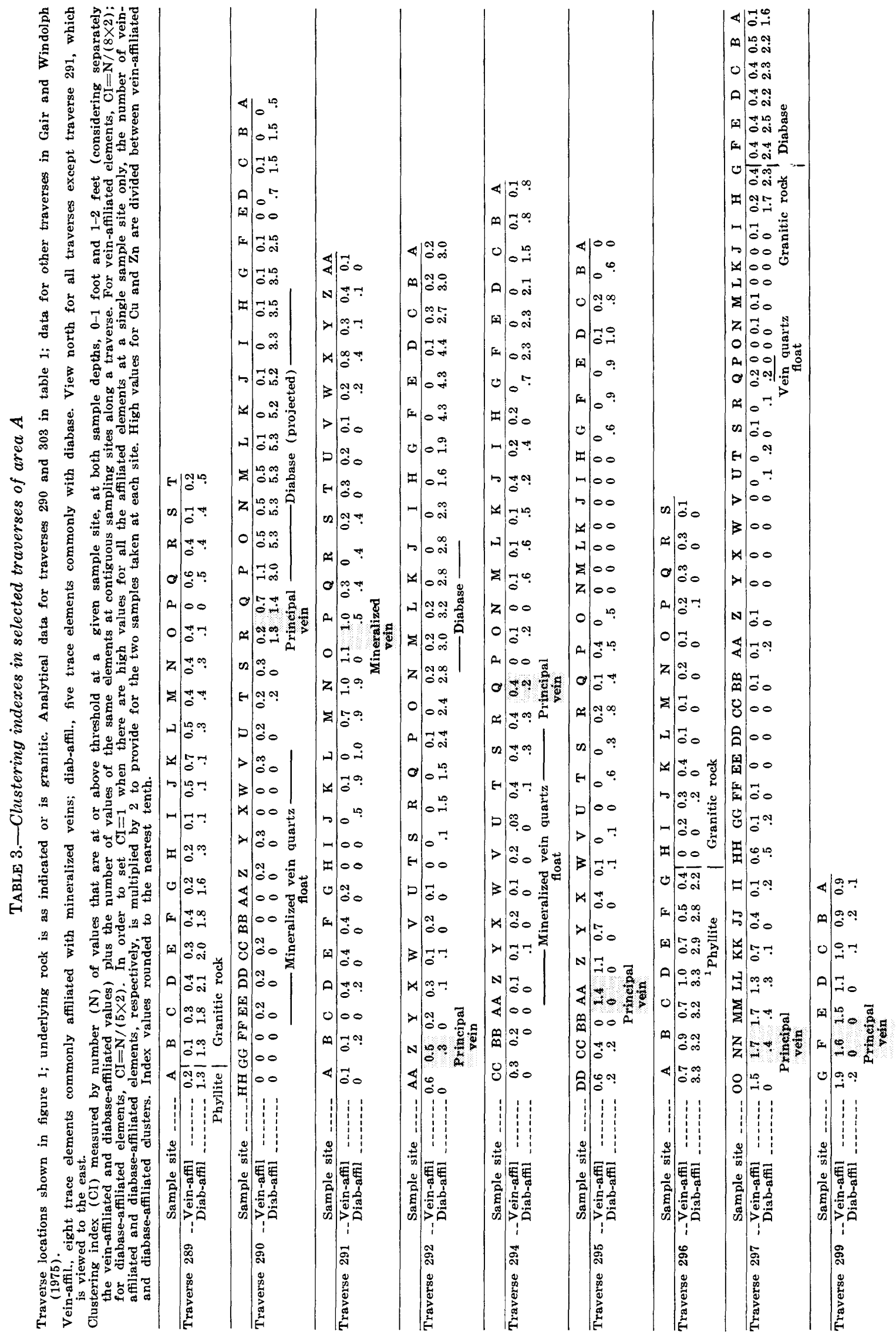




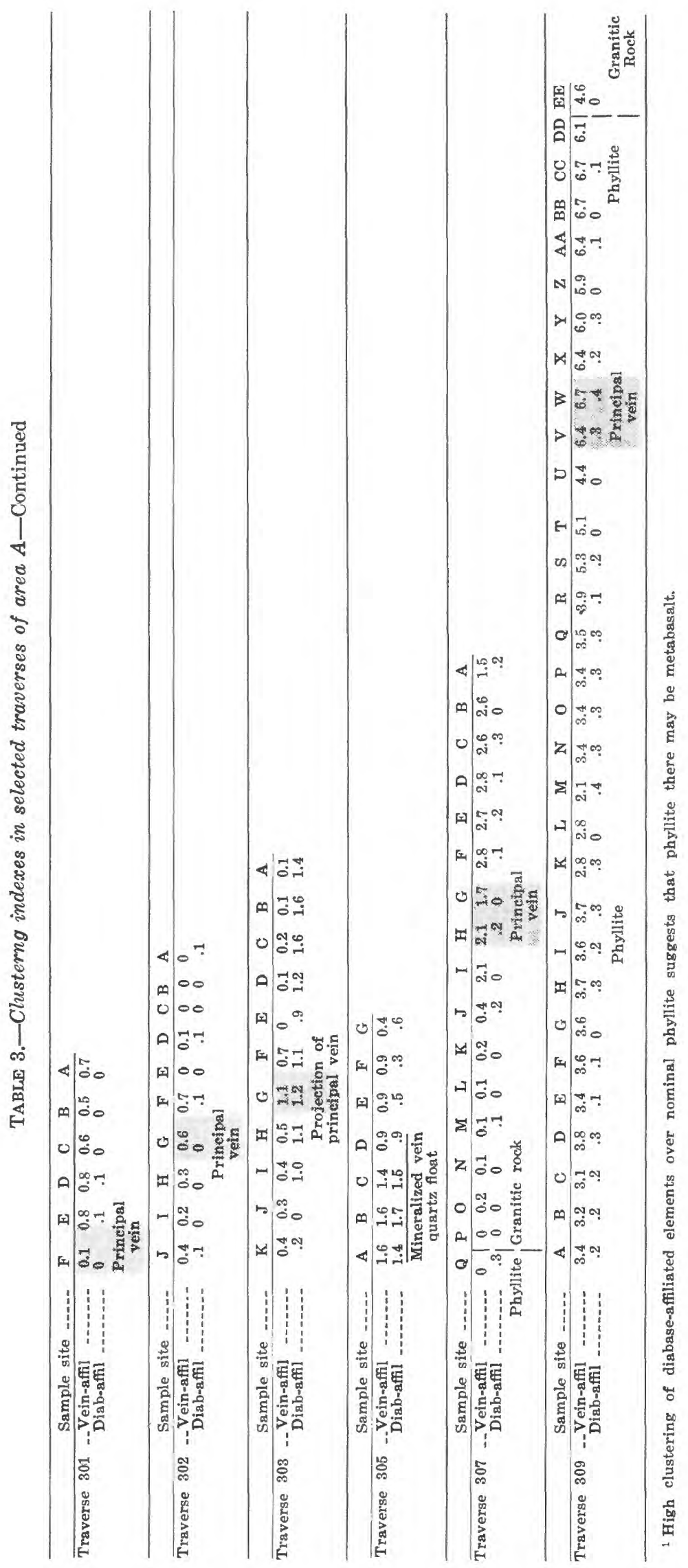


Sample location, value in ppm

Isopleth, dashed where approximately located

Areas with copper values of:

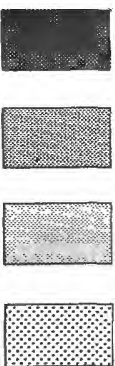

$>200 \mathrm{ppm}$

100 to $200 \mathrm{ppm}$

to $100 \mathrm{ppm}$

20 to $50 \mathrm{ppm}$

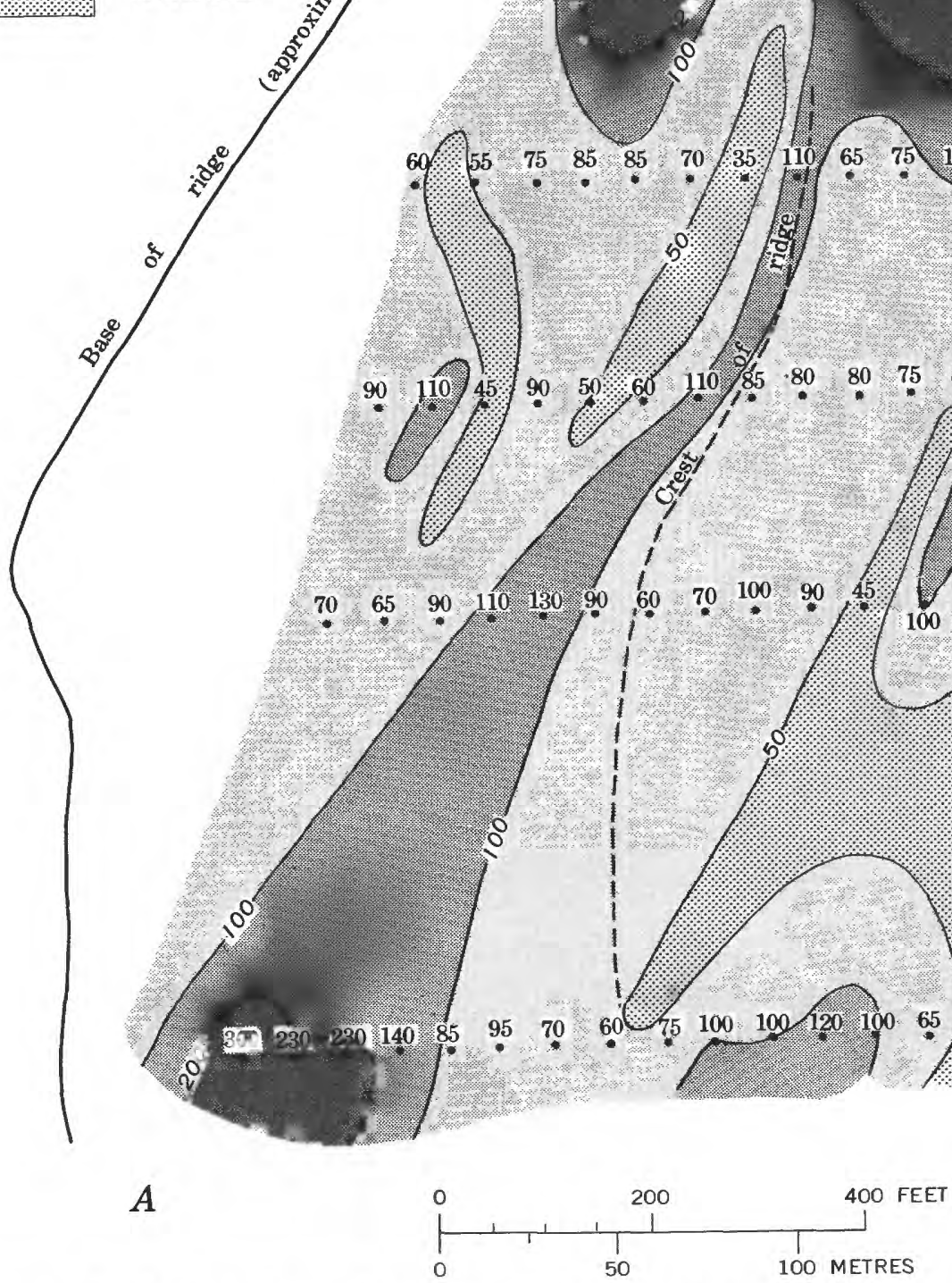

to 50 ppm

FIGURE 3.-Isopleth maps of geochemical data showing areas of high bismuth, copper, and molybdenum values. $A$, Copper values at depth of 1 to 2 feet; analytical method: atomic absorption. $B$, Molybdenum values at depth of 1 to 2 feet; analytical method: colorimetric. $C$, Bismuth values at depth of 1 to 2 feet; analytical method: semiquantitative spectrographic. 


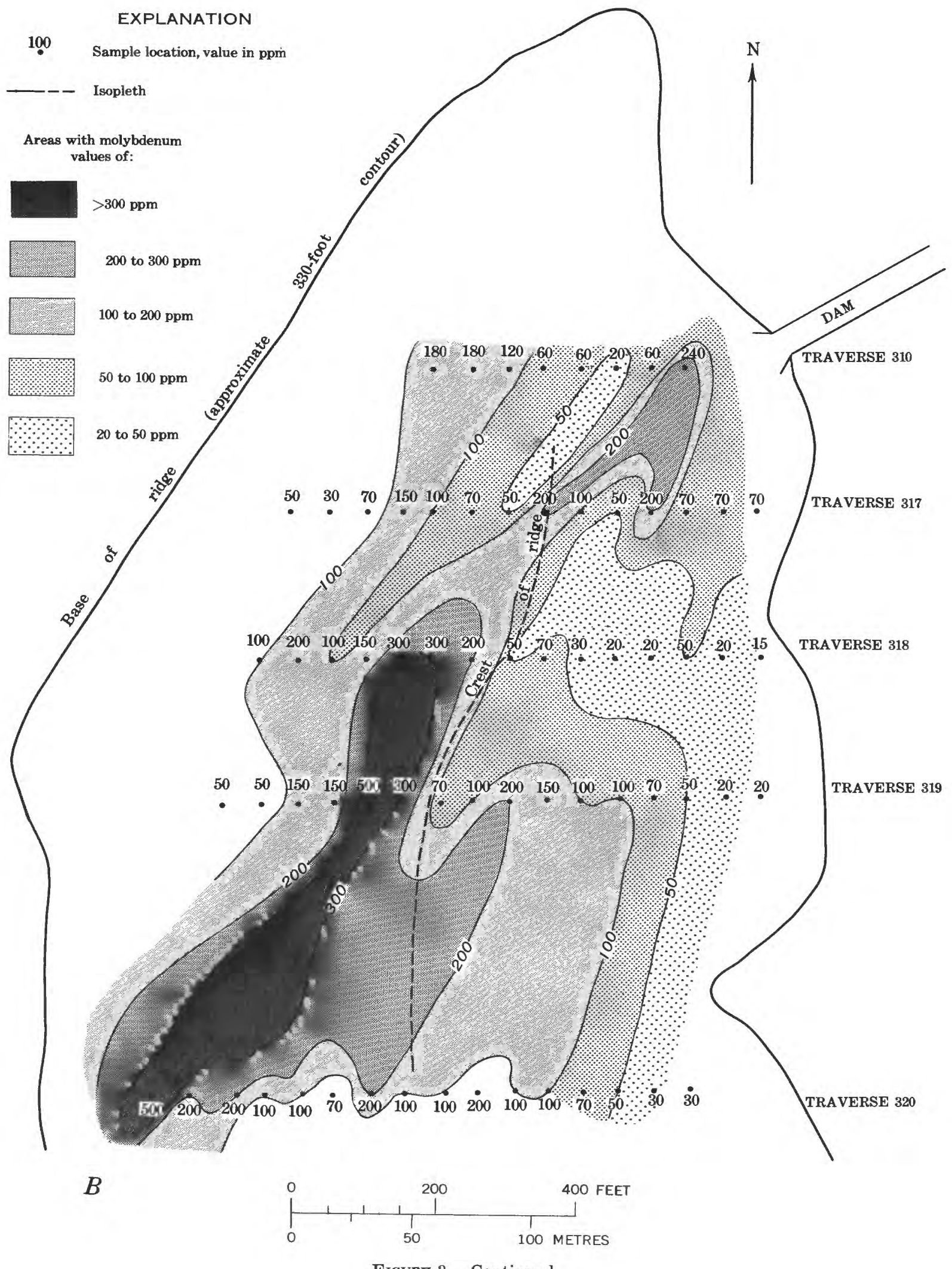

FIGURE 3.-Continued 


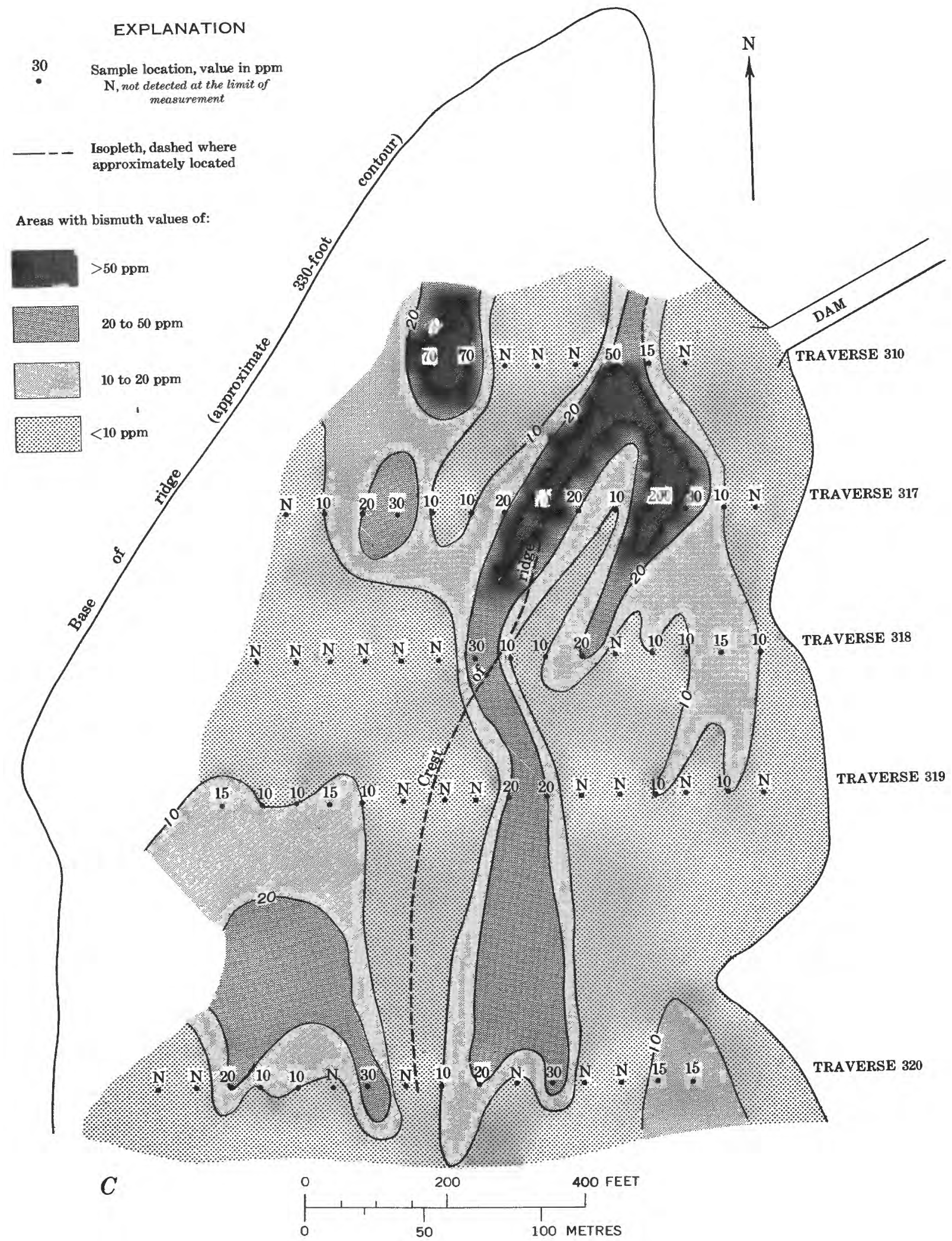

Figure 3.-Continued 
in area $A$, is unusually wide (providing the suggested mineralization follows approximately the regional trend here and is crossed at a large angle by the traverse). Despite the presence of quartz veins south of traverse 313 , there is no indication in the soil samples that tungsten mineralization reaches south of that traverse. On some of the other traverses in area $C$, there are small clusters of high values for copper, lead, zinc, or beryllium, which mainly appear not to be associated spatially with one another and probably are not significant.

\section{CONCLUSIONS}

The orientation survey shows that tungsten mineralization of ore grade (about half a percent or more tungsten) produces spectrographically measurable tungsten values in soil where veins reach the land surface or contribute noticeable float to the soil. Higher tungsten values, however, commonly are only a few times higher than the smallest amounts of tungsten that can be measured in samples by the spectrographic method used. Soil samples from areas of weakly mineralized vein quartz, well below ore grade, are not likely to contain measurable amounts of tungsten.

The area of high bismuth-copper-molybdenum values is interpreted as a reflection of more abundant minerals containing these elements in the vein or veins underlying that area than in the tungsten-bearing veins to the east.
Also, the magnitude and continuity of the high values of copper and molybdenum probably express the greater solubility of the copper and molybdenum minerals than huebnerite and the easier dispersal of copper and molybdenum than of tungsten by chemical weathering. The presence of a zone relatively rich in bismuth, copper, and molybdenum adjacent to the zone of tungsten veins might be caused by temperature zoning of original ore fluids.

\section{REFERENCES CITED}

Bell, Henry III, 1973, Some results of geochemical sampling in McCormick County, South Carolina: U.S. Geol. Survey Bull. 1376, 22 p.

Butler, J. R. and Ragland, P. C., 1969, A petrochemical survey of plutonic intrusions in the Piedmont, southeastern Appalachians, U.S.A: Contr. Mineralogy and Petrology, v. 24, no. 2, p. 164-190.

Espenshade, G. H., 1947, Tungsten deposits of Vance County, North Carolina, and Mecklenburg County, Virginia: U.S. Geol. Survey Bull. 948-A, 17 p.

Gair, J. E., and Windolph, J. F., Jr., 1975, Geochemical soil sampling traverses, Hamme tungsten district, North Carolina. Traverses 289-299; 301-323. U.S. Geol. Survey, open-file report, 3 p., 32 tables.

Hawkes, H. E., and Webb, J. S., 1962, Geochemistry in mineral exploration: New York Harper and Row, $415 \mathrm{p}$.

Miesch, A. T., 1967, Methods of computation for estimating geochemical abundance: U.S. Geol. Survey Prof. Paper 574-B, 15 p.

Parker, J. M. 3d, 1963, Geologic setting of the Hamme tungsten district, North Carolina and Virginia: U.S Geol. Survey Bull. 1122-G, 69 p. 


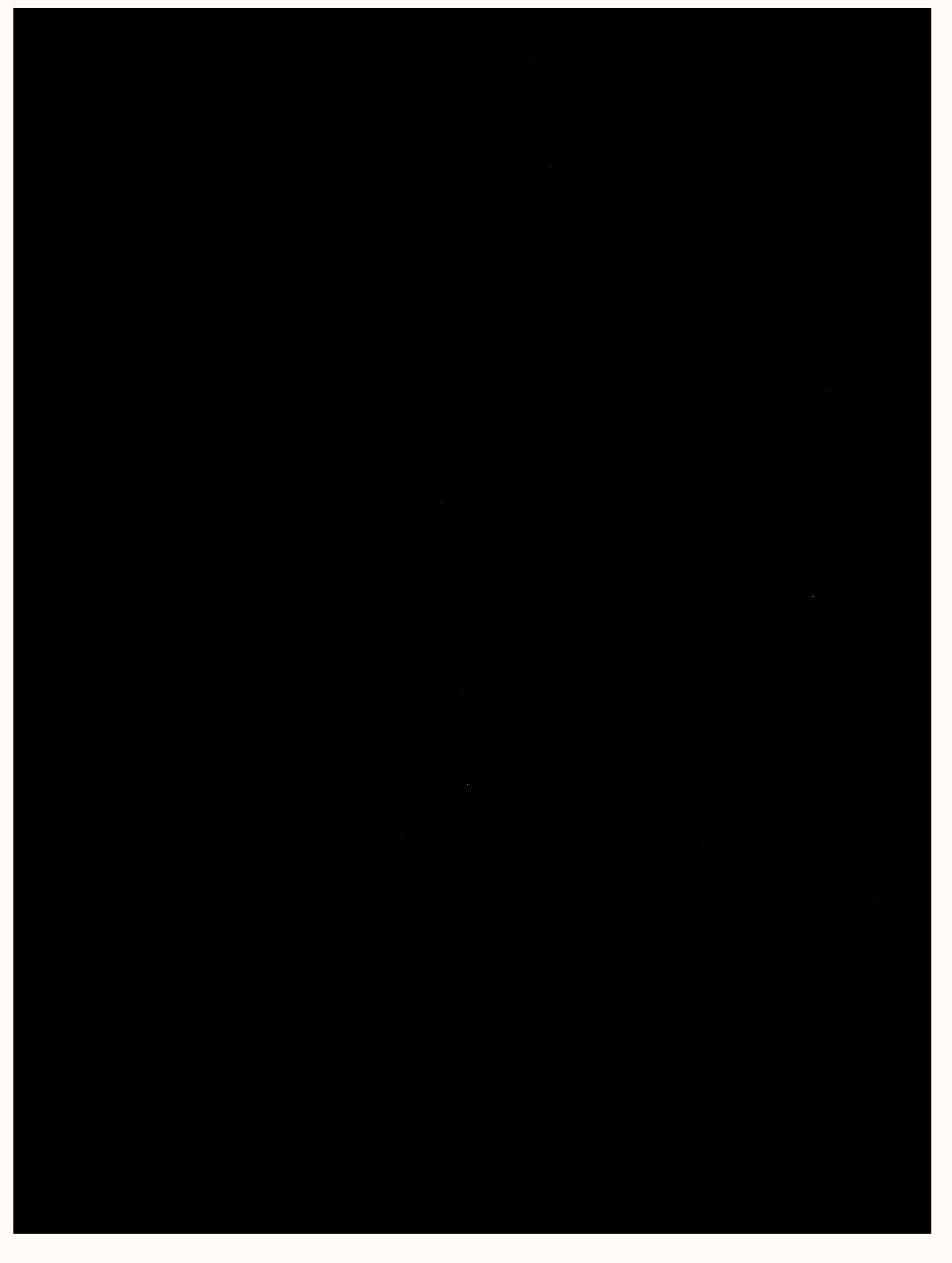




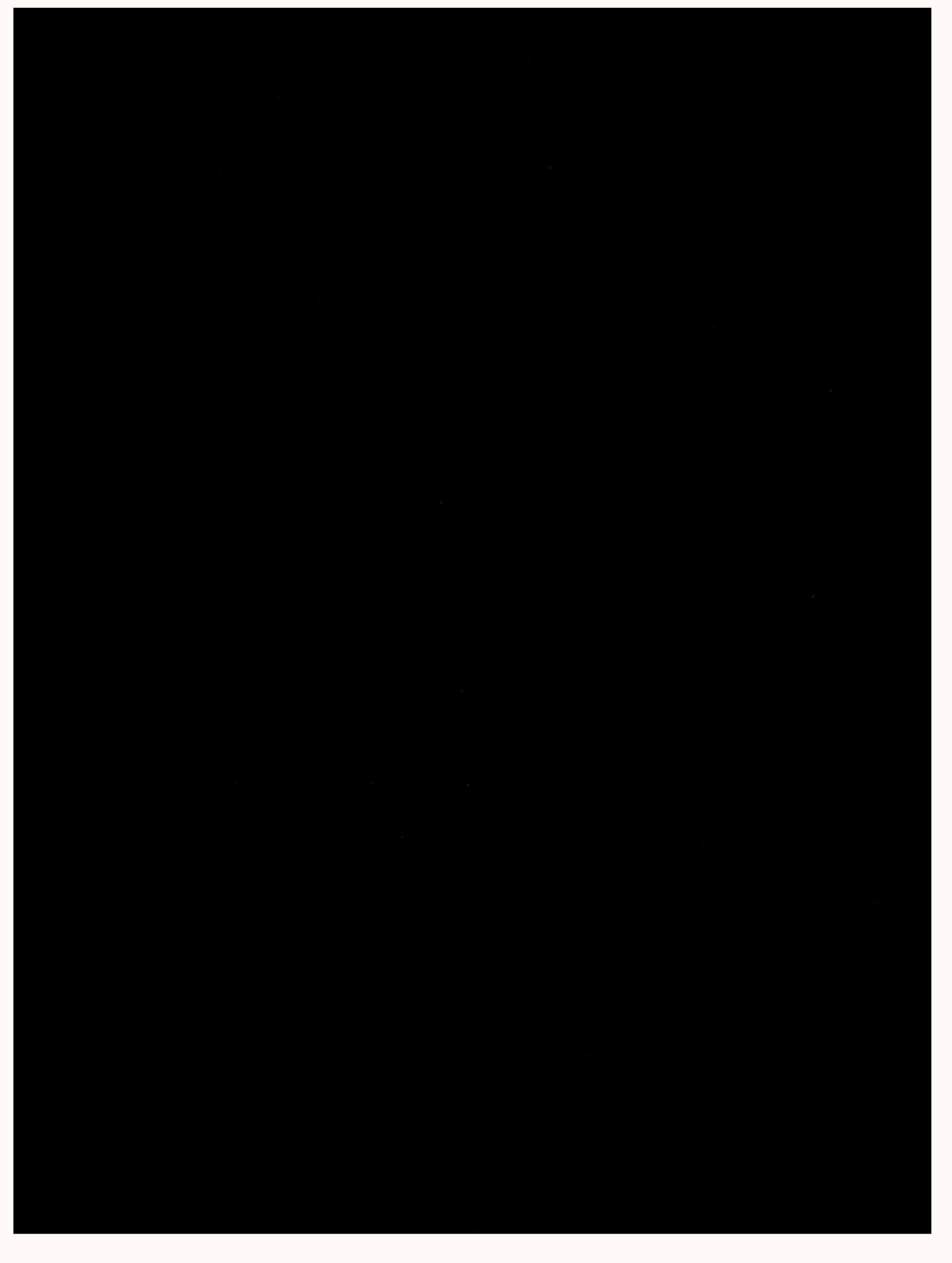

